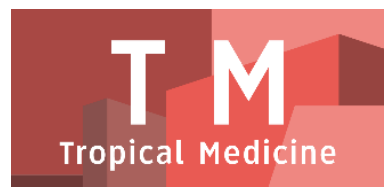

PAPER - OPEN ACCESS

\title{
Fusobacterium Nucleatum : Bakteri Anaerob pada Lingkungan Kaya Oksigen (Dihubungkan dengan Staterin Saliva)
}

\author{
Author : Yumi Lindawati \\ DOI $\quad: 10.32734 / \mathrm{tm} . v 1 \mathrm{i} 1.58$ \\ Paper Page : $181-188$
}

Volume 1 Issue 1 - 2018 TALENTA Conference Series: Tropical Medicine (TM)

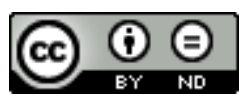

This work is licensed under a Creative Commons Attribution-NoDerivatives 4.0 International License.

Published under licence by TALENTA Publisher, Universitas Sumatera Utara
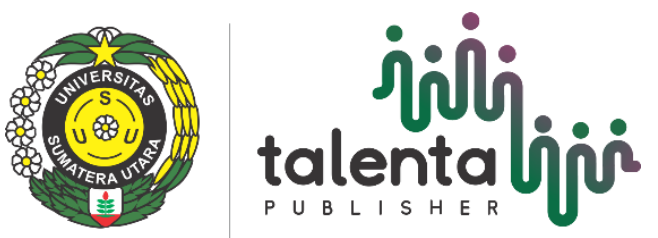


\title{
Fusobacterium Nucleatum : Bakteri Anaerob pada Lingkungan Kaya Oksigen (Dihubungkan dengan Staterin Saliva)
}

\author{
Yumi Lindawati ${ }^{\mathrm{a}}$, Ameta Primasari ${ }^{\mathrm{a}}$, Dwi Suryanto ${ }^{\mathrm{b}}$ \\ ${ }^{a}$ Fakultas Kedokteran Gigi, Laboratorium Mikrobiologi dan Laboratorium Terpadu Fakultas Kedokteran USU Medan,20155 \\ ${ }^{b}$ Fakultas MIPA Universitas Sumatera Utara, Medan,20155 \\ drg.yumi@yahoo.com
}

\begin{abstract}
Fusobacterium nucleatum pada plak gigi berperan penting sebagai jembatan peralihan antara kolonisasi bakteri awal plak gigi dengan kolonisasi bakteri berikutnya, khususnya bakteri anaerob obligat. Fusobacterium nucleatum merupakan bakteri anaerob obligat, namun membran terluar $F$. nucleatum secara spesifik mengikat asam amino ke-21 dan 26 dari molekul staterin yang berasal dari saliva sehingga memungkinkan bakteri ini dapat tumbuh pada saliva dan plak supragingiva. Penelitian ini bertujuan untuk mengetahui keberadaan dan jumlah koloni $F$. nucleatum, konsentrasi staterin, korelasi keduanya pada saliva dan plak supragingiva. Penelitian observasional ini menggunakan desain cross- sectional pada 28 sampel Unstimulated whole saliva menggunakan metode spitting dan plak supragingiva matang dilekatkan pada paper point nomor 60 dari pasien di Instalasi Periodonsia RSGMP FKG USU. Konsentrasi staterin dihitung menggunakan ELISA, jumlah koloni $F$. nucleatum dengan mengkultur sampel pada media Crystal Violet Erythromicyn, dilakukan perhitungan manual pada piring petri. Penelitian ini menemukan pertumbuhan koloni $F$. nucleatum dari sampel saliva dan plak supragingiva dalam jumlah sedikit. Median konsentrasi staterin diperoleh pada saliva $1,5 \mu \mathrm{g} / \mathrm{ml}(\mathrm{x}=2,35 \pm 2,71 \mu \mathrm{g} / \mathrm{ml})$ pada plak supragingiva $223 \mu \mathrm{g} / \mathrm{ml}(\mathrm{x}=332 \pm 242$ $\mu \mathrm{g} / \mathrm{ml})$. Secara teoritis bakteri ini berhubungan dengan staterin, akan tetapi pada penelitian ini secara statistik tidak dapat dikorelasikan pertumbuhannya dengan staterin. Simpulan penelitian ini membuktikan bahwa $F$. nucleatum dapat diperoleh dari lingkungan yang mengandung oksigen seperti pada saliva dan plak supragingiva, akan tetapi keterkaitannya dengan staterin saliva pada lingkungan tersebut memerlukan penjelasan lebih lanjut.
\end{abstract}

Kata Kunci : Fusobacterium nucleatum; staterin; saliva; plak supragingiva

\section{Pendahuluan}

Plak supragingiva pada permukaan sebuah gigi memiliki sekitar 109 sel bakteri yang melekat di dalamnya, pada saku periodontal yang sehat terdapat 103 sel bakteri sedangkan pada saku periodontal yang dalam ada sekitar 108 sel bakteri. Identifikasi secara biomolekuler menemukan sekitar 500 jenis mikroba terdapat pada plak gigi (Teughels dkk, 2012). Plak gigi, yang mengawali terjadinya kalkulus, merupakan ekosistem bakteri yang kompleks. Beberapa bakteri yang berperan dalam penyakit periodontal adalah bakteri gram negatif seperti Phorpyromonas gingivalis, Fusobacterium nucleatum, Aggregatobacter actinomycetemcomitans, dan bakteri gram positif seperti Lactobacillus, Streptococcus, Actinomyces israelli [10].

Hasil metabolisme suatu bakteri mendukung pertumbuhan bakteri lainnya pada plak gigi. F. nucleatum memainkan peranan penting sebagai jembatan peralihan antara kolonisasi bakteri awal plak gigi seperti 
Streptococcus spp. dengan kolonisasi bakteri berikutnya, khususnya bakteri anaerob obligat. Meskipun F. nucleatum merupakan bakteri anaerob obligat, pada kenyataannya bakteri ini dapat tumbuh dalam lingkungan rongga mulut yang mengandung oksigen (Dumitrescu, 2010). F. nucleatum merupakan bakteri gram negatif anaerob. Endotoksin dari bakteri ini akan mempengaruhi patogenesis dari penyakit periodontal (Samaranyake, 2012). Penelitian Nakagaki dkk [8] menemukan bahwa Protein 40-kDa pada F. nucleatum yang disebut dengan amplop (40-kDa CE) merupakan komponen mayor yang secara spesifik mengikat Tyrosin-Glutamin-Prolin-Valin-Glutamat (YQPVE) yang merupakan asam amino ke-21 dan 26 dari molekul staterin saliva, sebagai FomA, yaitu membran protein bagian luar dari $F$. nucleatum.

Staterin merupakan protein pelikel enamel yang menghalangi pertumbuhan dan pembentukan hidroksiapatit, melubrikasi permukaan enamel dan dapat dikenali oleh bakteri yang menyebabkan penyakit pada periodontal. Pada daerah terminal-C protein ini terikat pada fimbria bakteri yang menengahi perlekatan sel bakteri pada permukaan gigi [6].

Staterin pada pelikel gigi mengikat kristal hidroksiapatit pada permukaan enamel dan memberikan perlindungan tambahan melawan asam organik yang dihasilkan oleh organisme kariogenik [5]. Staterin menghambat pengendapan kalsium-fosfat dari saliva yang berikatan sangat jenuh dengan garam ini, hal ini mengindikasikan kemungkinan perannya dalam pembentukan pelikel dan plak (Fabian dkk, 2012). Staterin juga memfasilitasi perlekatan bakteri F. nucleatum pada permukaan gigi yang sebelumnya sudah terlebih dahulu mengikat kristal hidroksiapatit [8]. Kehadiran staterin pada pelikel dan saliva manusia, mengindikasikan bahwa ikatan antara staterin dan F. nucleatum berperan dalam pembentukan plak [12].

Ekologi mikrobial plak supragingiva tidak sejelas penjelasan ekologi mikrobial pada plak subgingiva yang sebagian besarnya adalah bakteri anaerob obligat. Penelitian Fyvie dkk [3], menunjukkan adanya kolonisasi bakteri F. nucleatum pada plak supragingiva individu yang sehat, dan koloni ini terlihat lebih banyak lagi tumbuh pada plak supragingiva individu yang mengalami periodontitis.

Berdasarkan penjelasan dan hasil penelitian tersebut di atas peneliti ingin mengetahui keberadaan Fusobacterium nucleatum pada saliva dan plak supragingiva yang diperoleh dari pasien sehat tanpa infeksi gingiva maupun jaringan periodontal dan mengevaluasi korelasinya dengan konsentrasi staterin pada saliva dengan plak supragingiva.

\subsection{Fusobacterium nucleatum}

Fusobacterium merupakan bakteri anaerob yang normal menempati rongga mulut, usus, saluran genital perempuan, dan dapat diisolasi dari paru dan abses pada tulang panggul. Fusobacterium nucleatum bakteri gram negatif anaerob obligat. Sel-selnya memiliki bentuk filamen yang panjang $(5-25 \mu \mathrm{m})$, atau berbentuk batang yang pleomorfik, produk metabolisme akhirnya berupa asam butirat. Bakteri ini biasa ditemukan pada saku periodontal dan gingiva krevikuler yang normal (Marsh \& Martin, 2009). Secara klinis, keberadaannya bersama spirochaeta menegakkan diagnosis gingivitis ulseratif akut. $F$. nucleatum memiliki subspesies yang diidentifikasi pada habitat yang berbeda, $F$. nucleatum subspesies polymorphum ditemukan pada gingiva krevikular yang sehat, $F$. nucleatum subsp nucleatum ditemukan pada saku periodontal dan $F$. nucleatum subsp vincentii biasanya pada infeksi tubuh bagian dalam (Samaranyake, 2012). Akan tetapi, penelitian Fyvie dkk [3] pada plak supragingiva dan subgingiva menemukan ketiga subspesies Fusobacterium pada plak supragingiva dan subgingiva meskipun dalam jumlah sedikit. Untuk mengkultur bakteri ini dapat dilakukan pada media blood agar dalam kondisi anaerob dengan bentuk koloni yang tidak cerah, berbentuk granular, tepi rhizoid, berbentuk irregular. Fusobacterium dapat membuang sulfur dari sistein dan metionin untuk memproduksi aroma hidrogen sulfida dan metilmerkaptan yang berhubungan dengan halitosis (Samaranyake, 2012).

Penelitian Diaz dkk [2] memukan bahwa dalam lingkungan $\mathrm{CO}_{2}$ pertumbuhan $F$. nucleatum 7,91 $\pm 0,05 \mathrm{CFU} / \mathrm{ml}$, dalam lingkungan yang sama dengan kondisi oksigen $10 \%$ pertumbuhannya $8,52 \pm 0,06 \mathrm{CFU} / \mathrm{ml}$ sedangkan pada level oksigen $20 \%$ masih dapat tumbuh 7,76 $\pm 0,16 \mathrm{CFU} / \mathrm{ml}$. Tanpa gas $\mathrm{CO}_{2}$ pada lingkungan tumbuh, secara anaerob $F$. nucleatum dapat tumbuh $7,98 \pm 0,18 \mathrm{CFU} / \mathrm{ml}$, pada level oksigen $10 \%$ pertumbuhannya $8,52 \pm 0,12$ $\mathrm{CFU} / \mathrm{ml}$ sedangkan pada level oksigen $20 \% \mathrm{~F}$. nucleatum masih dapat tumbuh walaupun dengan pertumbuhan yang lebih sedikit yaitu 7,36 $\pm 0,31 \mathrm{CFU} / \mathrm{ml}$. Fusobacterium nucleatum dapat dikultur dari plak supragingiva maupun pada plak subgingiva dengan perhitungan langsung (counting sel) maupun dengan identifikasi DNA [3]. 
Koagregasi Fusobacterium dipercaya menjadi jembatan mikroorganisme antara koloni di awal dan akhir pembentukan plak (Samaranyake, 2012). Perlekatan F. nucleatum pada biofilm (in vitro) berkurang oleh adanya bahan antimikroba seperti kloreksidin, triklosan, penisilin-G dan metronidazol. Dinding sel menjadi irregular akibat penyerapan antimokroba ini pada $F$. nucleatum, seperti yang terlihat pada Gambar 1 [9].

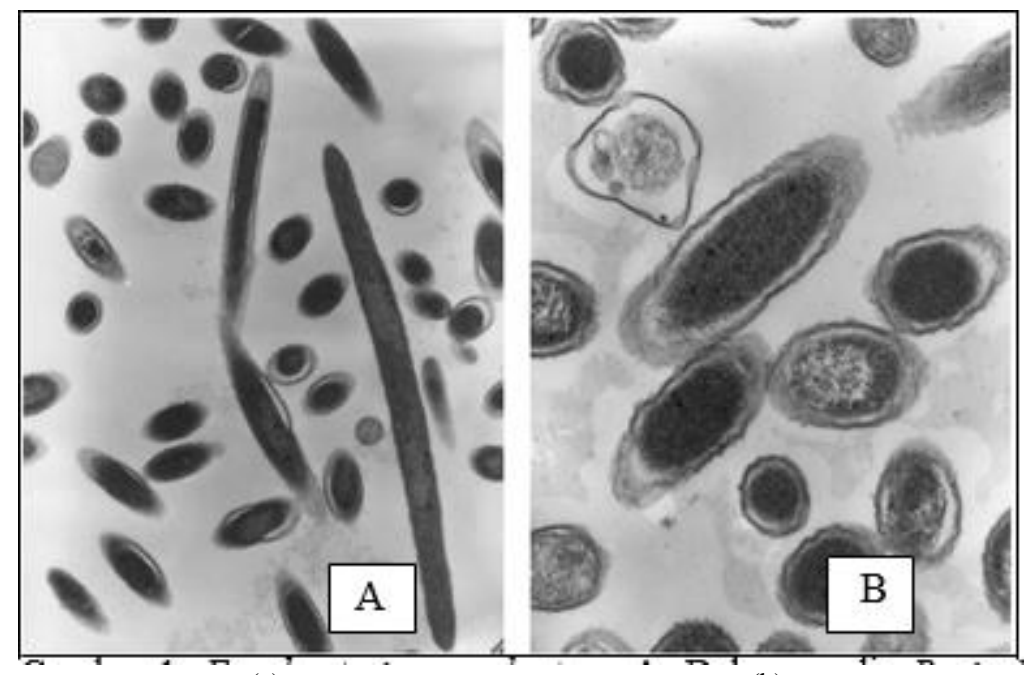

(a)

(b)

Gambar 1. Fusobacterium nucleatum. A. Dalam media Brain Heart Infussion (BHI) dengan mikroskop elektron perbesaran $28000 X$. B. Dinding sel Fusobacterium nucleatum menjadi irregular karena paparan kloreksidin atau penisilin G, mikroskop elektron, perbesaran 44360X

[9].

\subsection{Staterin}

Staterin pada saliva jumlahnya sekitar $0,01 \%$ dari total protein saliva [1]. Staterin juga merupakan salah satu komponen organik plak gigi (Eley dkk, 2010). Staterin saliva yang melewati pelikel gigi dapat dengan cepat terikat pada kalsium (hidroksiapatit) pada pelikel gigi. Hal ini dimungkinkan karena staterin memiliki terminal -amino yang bertanggungjawab terhadap perlekatan protein ini pada permukaan gigi [7]. Staterin diproduksi oleh kelenjar parotis dan kelenjar submandibula. Sebagai protein yang kaya akan tyrosin, staterin memiliki kemampuan tarik-menarik yang sangat kuat dengan kalsium hidroksiapatit. Rata-rata konsentrasi staterin pada whole saliva adalah $4,3 \mu \mathrm{g} / \mathrm{ml}, 95,9 \mu \mathrm{g} / \mathrm{ml}$ pada kelenjar parotis dan 73,6 $\mu \mathrm{g} / \mathrm{ml}$ pada kelenjar submandibula [6]. Proctor dkk [11] memperoleh rata-rata konsentrasi staterin pada saliva parotis adalah $37,7 \pm 8,5 \mu \mathrm{g} / \mathrm{ml}$ atau $7 \pm 1,5 \mathrm{nmol} / \mathrm{ml}$.

Diantara protein saliva manusia, staterin merupakan protein yang unik, fosfoprotein yang bebas karbohidrat. Staterin juga secara kuat diadsorpsi pada permukaan enamel gigi [8]. Staterin berukuran $5380 \mathrm{kDa}$, terdiri dari 43 susunan asam amino dan disamping tyrosin juga kaya akan prolin dan asam glutamat. Pada $2 / 3$ terminal-C protein, asam amino-asam amino ini terjadi repetisi multipel pada urutan di- dan tetrapeptida, yaitu : 4 x Glysin-Prolin, $3 \mathrm{x}$ Tyrosin-Glysin dan 2 x Prolin- Tyrosin-Glysin-Prolin. Terminal N ketiga dari molekul memiliki lebih banyak residu dengan kandungan ion negatif dibandingkan ion positif. Lima urutan residu asam yang terkandung didalamnya adalah satu asam aspartat, dua fosfoserin dan dua residu asam glutamat yang menempati urutan 1-5 pada terminal $\mathrm{N}$ dari staterin [6].

Staterin secara kompetitif mencegah absorpsi glikoprotein dengan berat molekul tinggi (HMWGPs) pada permukaan gigi, yang kemudian menghambat perlekatan HMWGP yang berikatan dengan bakteri, termasuk Streptococcus mutans. Staterin diadsorpsi dengan erat pada permukaan enamel yang memfasilitasi perlekatan $F$. nucleatum, A. viscosus, A. naeslundii dan $P$. gingivalis, ke permukaan hidroksiapatit yang telah diadsorbsi sebelumnya. Staterin mampu berikatan dengan protein permukaan sel $F$. nucleatum. Dua asam amino pada molekul sthaterin (YQPVPE =tyrosin-glutamin-prolin-valin- prolin-glutamat dan PYQPQYQ = prolin-tyrosin- 
glutamin-prolin-glutamin-tyrosin-glutamin) merupakan segmen yang paling sering berikatan dengan F. nucleatum. [8]. Secara alami, rantai penuh staterin berfungsi sebagai lubrikan, pelindung tekanan pengunyahan saat mengunyah makanan [6].

\section{Bahan Dan Metode}

Penelitian observasional ini dilakukan dengan desain cross-sectional, pengambilan 28 sampel saliva dan plak supragingiva dilakukan pada pasien di Instalasi Periodonsia Rumah Sakit Gigi dan Mulut Pendidikan (RSGMP) Fakultas Kedokteran Gigi USU dengan metode purposive sampling. Pemeriksaan konsentrasi staterin dilakukan dengan metode ELISA di Laboratorium Terpadu Fakultas Kedokteran USU sedangkan pemeriksaan sel Fusobacterium nucleatum menggunakan media Crystal Violet Erythromicyn dengan perhitungan manual dilakukan di Laboratorium Mikrobiologi Fakultas Kedokteran USU pada bulan Mei-Juni 2014.

Kriteria inklusi sampel adalah berusia 20 - 40 tahun, kesehatan umum baik, tidak dalam perawatan penggunaan antibiotik setidaknya dalam 3 bulan terakhir, memiliki kebiasaan menyikat gigi dengan pasta gigi, jumlah gigi tersisa minimal 20 gigi, memiliki plak supragingiva matang ( $\geq 48$ jam) ; memakai gel pendeteksi plak. Sedangkan kriteria eksklusi adalah perokok, penyirih, wanita hamil, menyusui, menopause, memakai pesawat ortodonti/gigi palsu cekat/lepasan, penyakit sistemik yang mempengaruhi kondisi saliva, penderita gingivitis dan periodontitis.

Alat-alat yang dipakai untuk penelitian ini adalah pot penampung saliva, paper point ukuran 60, Ice Blue Gel + termos es, Anaerobic Jar, kabin kabinet, autoclave, disposable loops dengan kalibrasi 10 $\mu$, centrifuge, kulkas 80oC, kuret, ELISA (Enzyme-Linked Immunosorbent Assays), mikkroskop elektrik (Olympus, CX 21), mikropipet. Bahan penelitian yang digunakan adalah sampel saliva dan plak supragingiva matang, media Crystal Violet Erithromycin (CVE), gas kit (AnaeroGen, Oxoid), BHI (Brain-Heart Infusion) : media transpor, PBS (Phosphat Buffered Saline) 1 X, Human Statherin ELISA Kit (Cusabio, China), Plaque ID Gel (GC, Amerika).

Pengambilan sampel unstimulated whole saliva dengan metode spitting yaitu sampel diminta untuk mengumpulkan saliva di dalam rongga mulut, kemudian diludahkan setiap 30 detik pada sebuah wadah penampung saliva, selama 5 menit. Pengambilan sampel saliva dilakukan $2 \mathrm{kali}: 2 \mathrm{ml}$ untuk perhitungan sel F. nucleatum, $2 \mathrm{ml}$ untuk pemeriksaan staterin. Sampel saliva disimpan dalam termos es berisi ice blue gel untuk menjaga suhu sampel $2-8 \mathrm{oC}$ sebelum dikirim ke laboratorium. Sampel saliva untuk pemeriksaan staterin disimpan dalam suhu $-80 \mathrm{oC}$ di laboratorium terpadu FK USU. Sampel untuk perhitungan sel bakteri F. nucleatum dikirim ke laboratorium mikrobiologi FK USU untuk dilakukan penanaman pada media CVE.

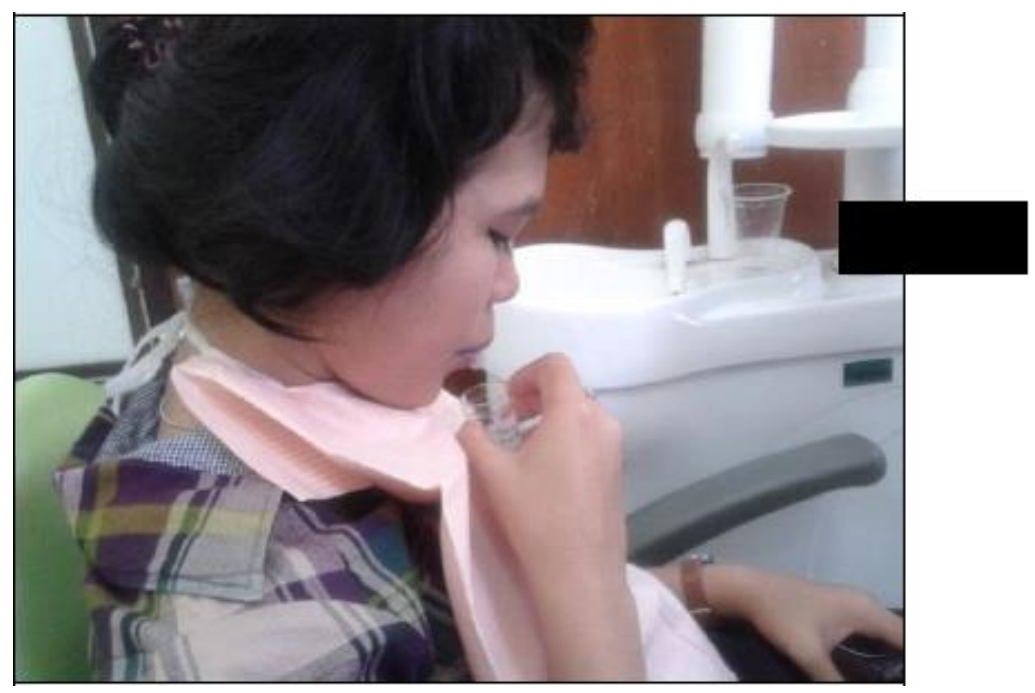

Gambar 2. Pengambilan sampel saliva (Dok) 
a. Pengambilan plak supragingiva matang dilakukan dengan cara, permukaan bukal gigi dikeringkan, Plaque ID Gel diaplikasikan pada seluruh permukaan gigi diatas margin gingiva, setelah 5 menit, plak yang berwarna biru (plak matang) diambil dengan menggunakan kuret steril, lalu direkatkan pada paper point no 60, sebanyak 2 kali untuk pemeriksaan bakteri dan staterin. Sampel plak untuk pemeriksaan kalsium, disimpan dalam vial berisi $100 \mu \mathrm{l}$ PBS $1 \mathrm{X}$, untuk pemeriksaan staterin dalam vial berisi $200 \mu \mathrm{l}$ PBS $1 \mathrm{X}$, dan untuk pemeriksaan $F$. nucleatum, dalam tabung berisi $10 \mathrm{~mL}$ BHI yang ditutup rapat.

b. Sampel plak yang telah dikumpulkan disimpan dalam termos es berisi ice blue gel untuk menjaga suhu sampel $2-8^{\circ} \mathrm{C}$ sebelum dikirim ke laboratorium.

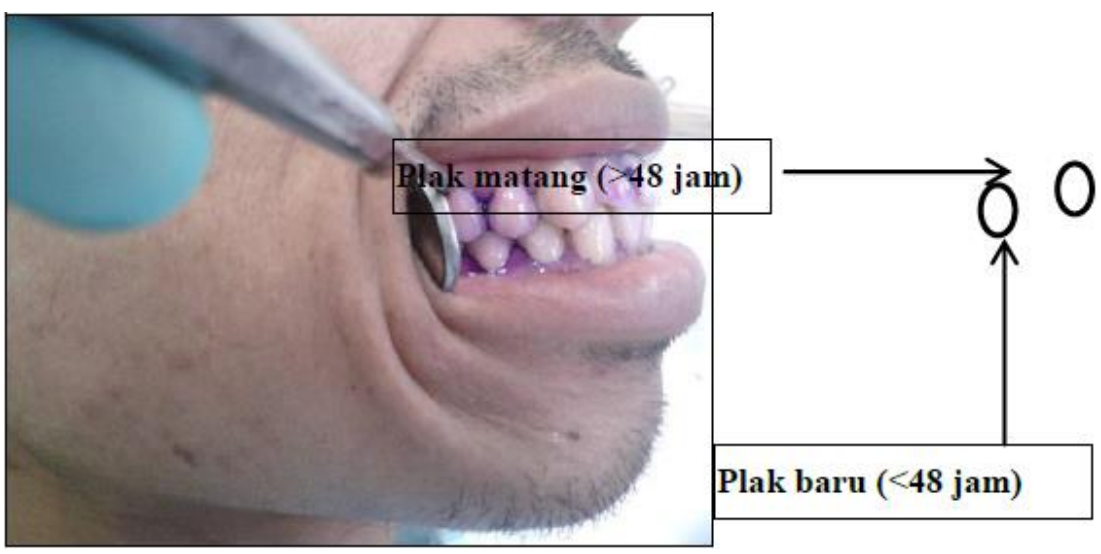

Gambar 3. Pengolesan ID Plaque Gel (Dok)

a. Pengkulturan bakteri, dilakukan dengan menggunakan media spesifik untuk Fusobacterium nucleatum yaitu Crystal Violet Erithromycin (CVE). Inkubasi pada suhu $37^{\circ} \mathrm{C}$ pada kondisi anaerob (anaerob jar) selama $2 \times 24$ jam koloni Fusobacterium nucleatum terlihat sangat khas dengan ciri-ciri halus, transparan, berwarna biru dengan inti gelap berdiameter sekitar $2 \mathrm{~mm}$.

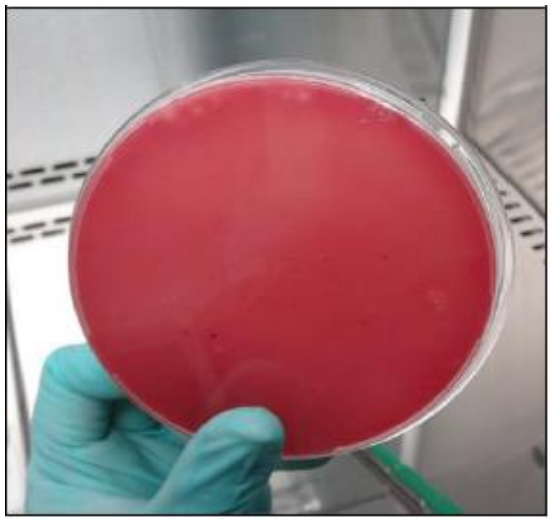

Gambar 4. Media CVE kosong (Dok)

Untuk mengidentifikasi, morfologi bakteri dari sampel dilakukan dengan pewarnaan gram. Mikroskopis sel bakteri Fusobacterium nucleatum berwarna merah berbentuk batang pleomorfik atau filamen (Marsh \& Martin, 2009). Bakteri gram negatif berbentuk batang kemudian di lakukan uji biokimia : glukosa (-), laktosa (-), maltosa $(-)$, sukrosa (-), indol (+ / cincin merah) (Krieg, Staley, Brown, Hedlun, Paster, Ward, dkk, 2010) dan tes sensitifitas : Penisilin-G (sensitif/S), Rifampisin (S), Kanamycin (S), Vankomisin (resisten) (Forbes, Sahm \& Weissfeld, 2007). Dilakukan perhitungan koloni diukur dalam satuan CFU (Coloni Forming Unit). Perhitungan dilakukan secara manual. 


\section{Hasil Penelitian}

Tabel 1. Rata-rata Konsentrasi Staterin dan Kalsium pada Saliva dan Plak Supragingiva

\begin{tabular}{llclc}
\hline \multirow{2}{*}{ Variabel Uji } & \multicolumn{2}{c}{ Saliva } & \multicolumn{2}{c}{ Plak Supragingiva } \\
\cline { 2 - 5 } & $\begin{array}{l}\text { Median } \\
(\text { Min }- \text { maks })\end{array}$ & Mean \pm SD & $\begin{array}{l}\text { Median } \\
(\text { Min - Maks })\end{array}$ & Mean \pm SD \\
\hline $\begin{array}{l}\text { Staterin } \\
(\mu \mathrm{g} / \mathrm{ml})\end{array}$ & $1,50(0,28-14,13)$ & $2,35 \pm 2,71$ & $223(25-914)$ & $332 \pm 242$ \\
\hline
\end{tabular}

Sedangkan untuk data jumlah sel Fusobacterium nucleatum tidak bisa dilakukan perhitungan statistik karena hanya terdapat 2 sampel yang menunjukkan pertumbuhan koloni sel Fusobacterium nucleatum yaitu pada 1 sampel saliva dengan jumlah sel sebesar $36 \mathrm{CFU} / 10 \mu \mathrm{l}$ dan 1 sampel plak supragingiva dengan jumlah sel sebesar 2 CFU/10 $\mu l$ yang berasal dari individu yang berbeda.

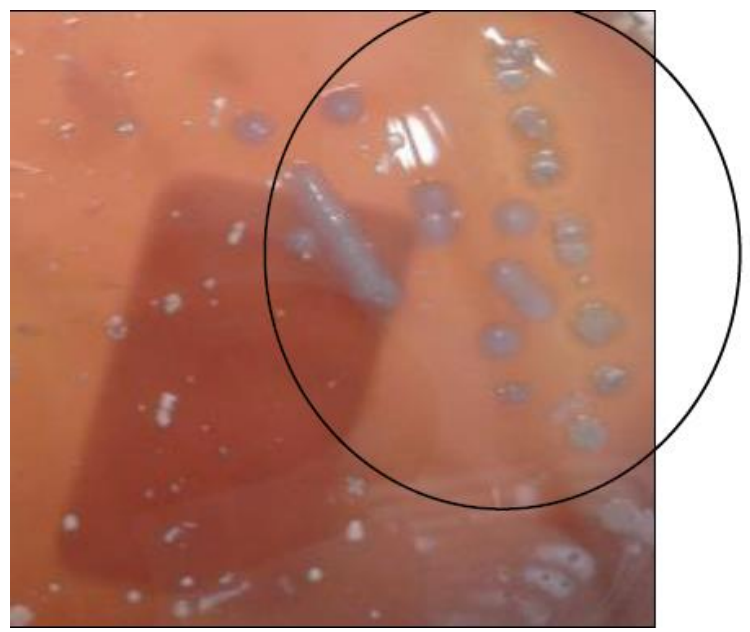

Gambar 6. Koloni sel F. nucleatum pada CVE dari sampel saliva (Dok)

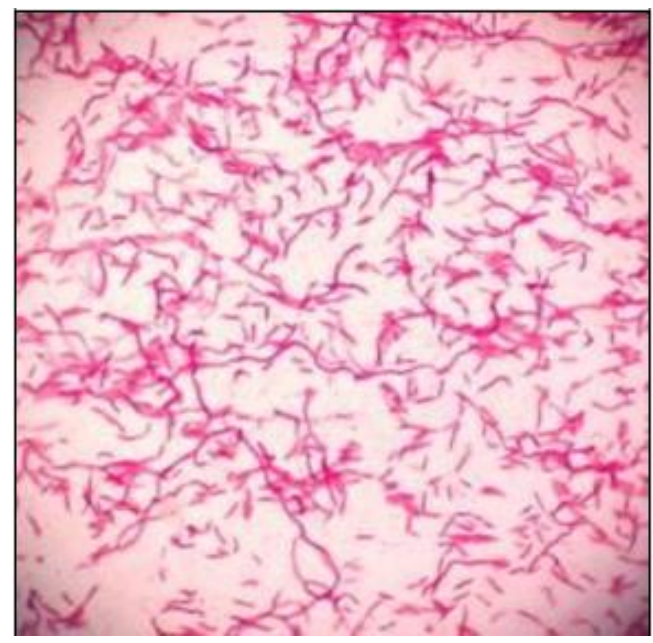

Gambar 7. Mikroskopis sel F. nucleatum pada pembesaran 1000 (Dok) 


\section{Pembahasan Dan Kesimpulan}

Penelitian He dkk (2012) secara in vitro menemukan bahwa jumlah F. nucleatum menurun signifikan dengan adanya hidrogen peroksidase (H2O2). Streptococcus sanguis memfasilitasi integrasi F. nucleatum pada bakteri gram positif yang mendominasi plak supragingiva. Di dalam plak, integrasi F. nucleatum dan streptococcus berbentuk corncob. Struktur ini yang diduga sebagai penghubung antara gram positif dan gram negatif. Sedangkan spesies streptococcus merupakan bakteri yang memiliki kemampuan mengekskresi hidrogen peroksidase. Hal ini semakin menguatkan dugaan bahwa plak matang yang diambil haruslah plak dimana komunitas bakteri streptococcus sudah mengalami penurunan kuantitas. Sehingga perlu penelitian lebih lanjut mengenai proses perlekatan F. nucleatum pada bakteri koloni awal dan bakteri koloni akhir dan bilamana kondisi plak dalam keadaan penurunan spesies streptococcus.

Staterin merupakan protein saliva yang mempunyai kemampuan untuk mengikat F. nucleatum. Akan tetapi Helmerhorst dkk [6] mengungkapkan enzim proteolisis dapat menyebabkan terpisahnya N-terminal staterin dari Cterminal. Sedangkan staterin yang diadsorpsi pada permukaan mineral (hidroksiapatit) di N-terminal, mengubah bentuk C-terminal staterin menjadi alfa-heliks. Bentuk ini dipercaya mengakibatkan munculnya epitopes yang tersembunyi. Munculnya epitopes ini pada staterin memfasilitasi ikatan dengan bakteri tertentu. Akibatnya, jika Nterminal staterin terpisah maka fragmentasi staterin di rongga mulut justru akan mencegah ikatan bakteri pada epitopes C-terminal. Hal ini menjadi penyebab yang diduga peneliti, sehingga peneliti tidak mendapatkan pertumbuhan sel Fusobacterium nucleatum pada seluruh sampel saliva maupun plak supragingiva, meskipun diperlukan penelitian lebih lanjut untuk mengetahui bentuk staterin pada saliva dan plak supragingiva serta enzim apa yang mempengaruhi proteolisis pada $\mathrm{N}$-terminal staterin.

Hasil yang diperoleh peneliti mendukung hasil yang diperoleh oleh Sekine dkk [12] secara in vitro telah menemukan bahwa terdapat 5 x 108 sel F. nucleatum pada $100 \mu 1,1 \mathrm{mM}$ staterin saliva. Sedangkan protein saliva hanya terdapat pada plak supragingiva. Hal ini memperkuat indikasi bahwa bahwa ikatan keduanya mempengaruhi pembentukan plak. Nakagaki dkk [8] mengidentifikasi protein membran terluar sel F. nucleatum (FomA $40 \mathrm{kDa}$ ) secara spesifik berikatan pada peptida aktif staterin yaitu pada YQPVPE (Tyrosin-Glutamin-Prolin-Valin-ProlinGlutamat).

Peneliti meyakini adanya hubungan yang sangat erat antara perlekatan F. nucleatum dengan staterin pada saliva dan plak supragingiva yang merupakan lingkungan yang mengandung oksigen, meskipun peneliti belum dapat membuktikan hubungannya secara statistik, tetapi keberadaan bakteri F. nucleatum, yang sejatinya di dalam referensi merupakan bakteri anaerob obligat, pada kedua lingkungan ini membuktikan kemampuan F. nucleatum untuk dapat hidup pada lingkungan kaya oksigen meskipun peneliti mengakui, peneliti perlu mengembangkan penelitian ini untuk dapat lebih menguatkan hasil yang telah diperoleh.

\section{Referensi}

[1] Amado F, Lobo MJ, Domingues P, Duarte JA, Vitorino R., 2010. Salivary peptidomics. Expert Rev Proteomics ; 7 (5) : $709-21$.

[2] Diaz PI, Zilm PS, and Rogers AH., 2002. Fusobacterium nucleatum supports the growth of Porphyromonas gingivalis in oxygenated and carbondioxide depleted environment. Microbiology; 148 : 467-72.Dumitrescu AL, 2010. Etiology and pathogenesis of periodontal disease. London, Springer. 1-25.Eley BM, Soory M and Manson JD., 2010. Periodontics. 6th edition. Toronto, Elsevier. 19-25.

[3] Fyvie LAX, Haffajee AD and Socransky SS, 2000. Comparison of the microbiota os supra- and subgingival plaque in health and perodontitis. J Clin Periodontol ; 27 : 648-57.

[4] Garcia-Godoy F and Hicks MJ, 2008. Maintaining the integrity of the enamel surface: the role of dental biofilm, saliva and preventive agents in enamel demineralization and remineralization. JADA;139 (suppl 2) : 25S-34S.

[5] Goobes G, Goobes R, Furman OS, Baker D, Stayton PS, Drobny GP, 2006. Folding of the c- terminal bacterial binding domain in statherin upon adsorption onto hydroxyapatite crystals. PNAS ; $103: 44: 16083-8$.

[6] Helmerhorst EJ, Traboulsi G, Salih E and Oppenheim FG., 2010. Mass spectrometric identification of key proteolytic cleavage sites in statherin affecting mineral homeostasis and bacterial binding domains. J Proteome Res ; 9 (10) : 5413-21.

[7] Jin Y and Yip HK, 2002. Supragingival calculus : formation and control. CROBM ; 13 ; 5 : 426-41. Marsh PD and Martin MV, 2009. Oral microbiology, 5th Edition. Toronto, Churchill Livingstone-Elsevier. 74-102.

[8] Nakagaki H, Sekine S, Terao Y, Toe M, Tanaka M, Ito HO, et al, 2010. Fusobacterium nucleatum envelope protein fom A is immunogenic and binds to the salivary statherin-derived peptide. Infection and Immunity ; Mar : 1185-92.

[9] Okamoto AC, Jardim EG, Chavez VE, Campos MJ., 2002. Influence of subinhibitory concentration of antimicrobial on hydrophobicity, adherence and ultra-structure of Fusobacterium nucleatum. Brazillian Journal of Microbiology ; 33 : 178-184. 
[10] Perry DA and Beemsterboer PL, 2007. Periodontology for the dental hygienist. 3rd Edition. St. Louis, Saunders-Elsevier. 62-70

[11] Proctor GB, Hamdan S, Carpenter GH and Wilde P., 2005. A statherin and calcium enriched layer at the air einterface of human parotid saliva. Biochem J ; $389: 111-6$

[12] Sekine S, Kataoka K, Tanaka M, Nagata H, Kawakami T, Akaji K, et al, 2004. Active domains of salivary statherin on apatitic surfaces for binding to Fusobacterium nucleatum cells. Microbiology ; $150: 2373-79$. 